\title{
PENGARUH MODEL PEMBELAJARAN THINK PAIR SHARE TERHADAP KEMAMPUAN PEMAHAMAN KONSEP MATEMATIS SISWA KELAS VII MTs YASTI SHALAHUDDIN SINGKAWANG
}

\author{
Rudi $^{1}$, Eka Murdani ${ }^{2}$, Mariyam ${ }^{3}$ \\ Pendidikan Matematika ${ }^{1,3}$, Pendidikan Fisika ${ }^{2}$, STKIP Singkawang, Singkawang, Indonesia \\ rudispd49@gmail.com ${ }^{1}$, eka.murdani.5@gmail.com ${ }^{2}$, mariyam.180488@ gmail.com ${ }^{3}$
}

\section{Kata Kunci: \\ Model Think Pair Share; \\ Kemampuan Pemahaman \\ Konsep Matematis}

\begin{abstract}
ABSTRAK
Penelitian ini bertujuan untuk mengetahui pengaruh model pembelajaran Think Pair Share terhadap kemampuan pemahaman konsep matematis siswa. Penelitian ini dilaksanakan di MTs YASTI Shalahuddin Singkawang. Metode yang digunakan dalam penelitian ini adalah metode eksperimen, bentuk penelitian yang digunakan Pre-Eksperimen Design dengan One Group Pre-test Post-test Design. Sampel penelitian menggunakan Sampling Jenuh, yaitu semua siswa kelas VII dengan jumlah 31 siswa sebagai kelas eksperimen. Data menunjukkan bahwa: 1) Hasil perhitungan kemampuan pemahaman konsep matematis siswa ditunjukkan dengan nilai rata-rata post-test 72,58. Dari data tersebut dilakukan analisis data menggunakan uji-t dua sampel berpasangan, diperoleh nilai $t_{\text {hitung }}$ sebesar 32,47 dan $t_{\text {tabel }}$ sebesar 2,0003 dengan taraf signifikan $5 \%$, karena ( $\left.t_{\text {hitung }}>t_{\text {tabel }}\right)$ maka dapat dikatakan hipotesis alternatif $(\mathrm{Ha})$ diterima dan hipotesis nol (Ho) ditolak. Hal ini menunjukkan bahwa terdapat pengaruh model pembelajaran Think Pair Share terhadap kemampuan pemahaman konsep matematis siswa pada materi himpunan. 2) Hasil perhitungan aktivitas menggunakan model pembelajaran Think Pair Share menunjukkan sebesar 90,82\% kriteria sangat tinggi. 3) Hasil perhitungan angket respon siswa keseluruhan memberikan respon yang positif terhadap model pembelajaran Think Pair Share pada materi himpunan yang diterapkan mulai dari kriteria baik hingga sangat baik.
\end{abstract}

\section{PENDAHULUAN}

Matematika merupakan mata pelajaran yang penting untuk diajarkan kepada siswa disekolah. Hal ini dapat dilihat dari banyaknya aktivitas masyarakat yang cenderung berhubungan dengan matematika atau berhitung. Belajar matematika hendaknya tidak disamakan dengan ilmu yang lain karena belajar matematika tidak hanya mengetahui dan memahami ilmu yang terdapat di dalamnya, tetapi menuntut siswa berpikir secara kritis, logis, dan tepat Buyung, B., \& Dwijanto, D. (2017). Hal ini sesuai dengan prinsip-prinsip National Council of Teacher Mathematics (NCTM). Menurut NCTM (dalam Walle, 
2011: 3) prinsip tersebut menyatakan bahwa mengajar matematika yang efektif memerlukan pemahaman tentang apa yang siswa ketahui dan diperlukan untuk belajar, kemudian memberi tantangan dan mendukung mereka untuk mempelajarinya dengan baik. Pernyataan tersebut menyatakan bahwa pemahaman konsep sangat penting dalam pembelajaran matematika. Menurut Jaenab (2014: 254) sesuai dengan tujuan National Council of Teachers of Mathematics (NCTM) yang menetapkan lima standar kemampuan matematis yang harus dimiliki, yaitu kemampuan pemecahan masalah, kemampuan pemahaman konsep, kemampuan koneksi, kemampuan penalaran, dan kemampuan representasi.

Prinsip-prinsip NCTM juga telah dinyatakan dalam tujuan pembelajaran matematika pada kurikulum KTSP (Depdikdas, 2006), dimana siswa diharapkan memiliki kemampuan pemahaman konsep matematika, menjelaskan keterkaitan antar konsep dan mengaplikasikan konsep atau alogaritma, secara luwes, akurat, efesien, dan tepat dalam pemecahan masalah. Gagasan mengenai pemahaman konsep menurut Wardhani (2008: 10-11) dan peraturan Dirjen Dikdasmen Nomor 506/C/Kep/PP/2004 menyatakan bahwa indikator siswa memahami konsep matematika adalah (1) menyatakan ulang sebuah konsep, (2) mengklarifikasi objek menurut sifat-sifat tertentu sesuai dengan konsepnya, (3) memberi contoh dan bukan contoh dari suatu konsep, (4) menyajikan konsep dalam berbagi bentuk reprentasi matematika, (5) mengembangkan syarat perlu atau syarat cukup dari suatu konsep, (6) menggunakan dan memanfaatkan serta memilih prosedur atau operasi tertentu, dan (7) mengaplikasikan konsep atau alogaritma pada pemecahan masalah. Berdasarkan hasil uraian di atas, terlihat bahwa pemahaman konsep penting dalam pembelajaran matematika, sehingga dapat menjadi pedoman guru dalam pembelajaran matematika.

Pada pembelajaran matematika memuat materi himpunan.himpunan satu di antara materi yang dipelajari pada tingkat SMP sederajat dan merupakan materi yang diangap sulit untuk dipecahkan. Hal ini sesuai dengan hasil penelitian Novita (2014) mengenai kemampuan pemahaman konsep matematis siswa, ditemukan bahwa terdapat tiga kesulitan yang dialami dalam mengerjakan soal antara lain: (1) kesulitan dalam memahami soal; (2) kesulitan dalam operasi hitung pada himpunan; (3) kesulitan dalam menentukan konsep yang sesuai dengan yang telah dipelajari. Berdasarkan penelitian yang telah dilakukan, siswa mengalami kesulitan dalam kemampuan pemahaman konsep matematis karena belum mengerti dalam menyelesaikan soal yang berkaitan dengan materi himpunan, sehingga siswa menganggap materi himpunan itu sulit.

Dari hasil pra-riset tanggal 11 Oktober 2015 pada 31 orang siswa kelas VII MTs YASTI Shalahuddin Singkawang pada materi bilangan diketahui bahwa tingkat pemahaman konsep matematis siswa masih rendah. Hal tersebut dapat dilihat dari hasil pekerjaan siswa pada gambar berikut ini:

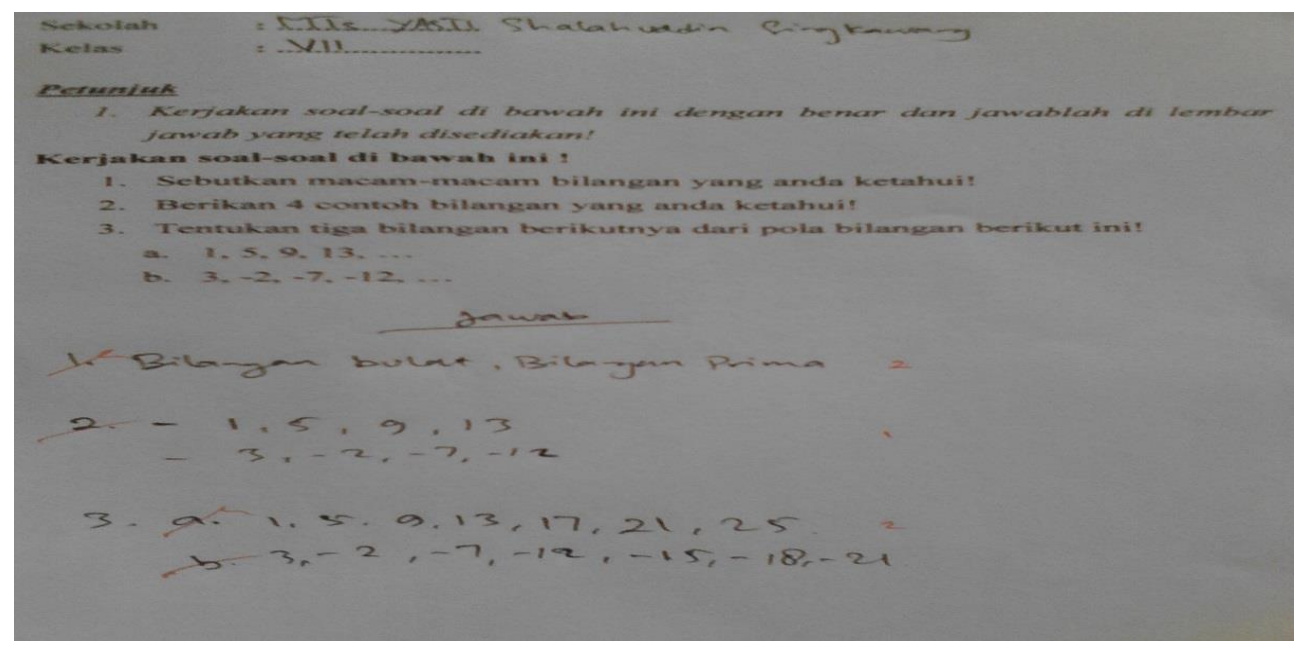

Gambar 1 hasil pra-riset siswa 
Hal ini dapat dilihat pada Gambar dari hasil pekerjaan soal-soal yang dikerjakan siswa terdapat 56\% siswa yang mengalami kesulitan menyatakan ulang sebuah konsep, dan siswa yang menjawab benar sebesar 44\% dari 31 siswa. Siswa mengalami kesulitan memberi contoh dan non-contoh dari suatu konsep sebanyak 35\% dan menjawab benar dan sebesar 65\% dari 31 siswa. Sebanyak 32\% siswa mengalami kesulitan mengklasifikasikan konsep ke pemecahan masalah dan menjawab dengan benar sebesar 68\% dari 31 siswa. Berdasarkan hasil pra-riset pada MTs YASTI Shalahuddin Singkawang pada ketiga indikator, maka dapat diketahui bahwa rendahnya pemahaman konsep matematis siswa dalam pembelajaran matematika.

Rendahnya kemampuan pemahaman konsep matematis siswa tersebut, disebabkan siswa mengalami kesulitan dalam menyelesaian soal atau siswa belum menguasai secara benar tentang materi yang dipelajari.Hal tersebut didukung oleh penelitian Slavin (2005: 153) yang menyatakan bahwa kemampuan pemahaman konsep matematis siswa masih rendah. Penyebab kemampuan pemahaman konsep matematis siswa rendah adalah karena kemampuan tersebut belum dikembangkan sejak dini, terutama pada usia Sekolah dasar (SD) sehingga kesalahan-kesalahan pada pemahaman siswa terbawa hingga jenjang berikutnya. Penyebab lain rendahnya pemahaman konsep matematis siswa diduga kegiatan pembelajaran matematika di kelas dilakukan dengan menggunakan model pembelajaran langsung, sehingga siswa kurang diajak belajar memahami tentang konsep.

Hal ini diperkuat dari hasil wawancara terhadap guru matematika MTs YASTI Shalahuddin Singkawang, proses belajar di dalam kelas masih kurang aktif dan cenderung pasif, siswa kurang dilibatkan dalam pembelajaran, sehingga aktivitas belajar siswa masih tergolong rendah.Kurang adanya kesadaran dan keinginan dari diri siswa untuk belajar, kurangnya dorongan untuk menumbuhkan minat belajar, serta kurangnya kemampuan pemahaman konsep matematis siswa sehingga menjadi penyebab dari rendahnya aktivitas belajar siswa tersebut.Selain itu, ditemukan bahwa masih terdapat siswa yang cenderung melalaikan kewajibannya untuk mengerjakan Pekerjaan Rumah (PR) dan siswa belum terlibat aktif dalam kegiatan pembelajaran matematika.Hal ini menunjukkan bahwa kurangnya respon dari siswa terhadap pembelajaran matematika.

Berdasarkan beberapapermasalahan di atas apabila tidak ditindak lanjuti, maka akibat yang akan terjadi kurangnya interaksi baik antara siswa dengan guru maupun siswa dengan siswa serta belum bisa menyelesaikan persoalan di dalam kelas. Kondisi ini dapat menyebabkan kurangnya kerjasama. Berdasarkan permasalahan yang dipaparkan, maka salah satu solusi yang dapat dilakukan adalah dengan memilih model pembelajaran yang tepat dalam proses pembelajaran agar siswa menjadi aktif dan bisa bekerjasama dalam menyelesaikan persoalan. Sehingga siswa menjadi tidak jenuh dan hasil yang diperoleh dalam pembelajaran matematika baik serta dapat meningkatkan kemampuan pemahaman konsep matematis siswa.Satu diantara yang di anggap dapat mengatasi hal tersebut yaitu melalui Model Pembelajaran Think Pair Share (TPS).

Model pembelajaran TPS adalah suatu model pembelajaran yang dianggap dapat dilakukan untuk mengatasi permasalahan pembelajaran siswa dalam meningkatkan kemampuan pemahaman siswa melalui Lembar Kerja Siswa (LKS) yang berdasarkan pada masalah yang mengandung pertanyaan dan belum tergambarkan dengan secara jelas dan ingin membangkitkan pengetahuan siswa. TPS merupakan cara yang dianggap efektif untuk mengubah pola diskusi dalam kelas. Strategi menantang tentang asumsi bahwa seluruh resitasi dan diskusi perlu dilakukan didalam setting seluruh kelompok.

TPS memiliki prosedur yang ditetapkan secara eksplisit untuk memberi siswa waktu lebih banyak untuk berpikir, menjawab dan saling membantu satu sama lain (Ibrahim, dkk, 2000: 26). Berdasarkan hasil penelitian yang dilakukan oleh Sutiarni (2013) bahwa model pembelajaran TPS pada siswa kelas VII SMP Negeri 2 Singkawang adalah efektif karena ketuntasan hasil belajar signifikan, aktivitas siswa aktif, dan respon siswa baik. TPS belum pernah diterapkan di kelas VII MTs YASTI Shalahuddin Singkawang.Dengan demikian diharapkan TPS dapat dilakukan untuk mengatasi masalah pembelajaran siswa dalam upaya meningkatkan kemampuan pemahaman konsep matematis siswa pada MTs YASTI Shalahuddin Singkawang di kelas VII. 
Model pembelajaran TPS merupakan cara efektif untuk mengubah pola diskusi dalam kelas. Strategi menantang tentang asumsi bahwa seluruh resitasi dan diskusi perlu dilakukan didalam setting seluruh kelompok. Think Pair Share memiliki prosedur yang ditetapkan secara eksplisit untuk memberi siswa waktu lebih banyak untuk berpikir, menjawab dan saling membantu satu sama lain (Ibrahim, dkk, 2000: 26). Sedangkan kemampuan pemahaman konsep matematis siswa adalah salah satu indikator pencapaian siswa memahami konsep-konsep matematika yang telah dipelajari selama proses pembelajaran (Murizal, 2012: 21).

Pelaksanaan model pembelajaran TPS diharapkan dapat meningkatkan kuantitas kemampuan pemahaman konsep matematis siswa, dan memberi siswa waktu lebih banyak untuk berpikir, menjawab, dan saling membantu satu sama lain. Berdasarkan hal tersebut, penulis tertarik melakukan penelitian dengan judul "Pengaruh Model Pembelajaran Think Pair Share Terhadap Kemampuan Pemahaman Konsep Matematis Siswa Kelas VII MTs YASTI Shalahuddin Singkawang".

\section{METODE PENELITIAN}

Jenis penelitian ini adalah jenis penelitian kuantitatif dengan metode eksperimen karena data yang diperoleh berhubungan dengan angka-angka yang dapat dihitung secara matematis dan sistematis. Penelitian ini menggunakan desain penelitian one group pre-test post-test design. Populasi dalam penelitian yang dilaksanakan ini adalah seluruh siswa kelas VII MTs YASTI Shalahuddin Singkawang.

Teknik pengambilan sampel yang digunakan adalah sampling jenuh. Teknik sampling jenuh adalah teknik penentuan sampel bila semua anggota populasi digunakan sebagai sampel. Jadi sampel pada penelitian ini adalah siswa kelas VII MTs YASTI Shalahuddin Singkawang. Teknik pengumpulan data pengukuran yang dimaksud dalam penelitian ini adalah dengan memberikan tes, yaitu tes awal (pre-test) dan tes akhir (post-test) kepada siswa mengenai himpunan, tes yang digunakan dalam penelitian ini berbentuk uraian (essay) yang terdiri dari 3 butir soal. Teknik yang digunakan adalah teknik observasi langsung dan teknik komunikasi tidak langsung. Observasi langsung untuk mengetahui aktivitas belajar siswa dalam proses pembelajaran pada materi himpunan. Teknik komunikasi tidak langsung digunakan untuk mengetahui respon dalam belajar dengan perlakuan. Dalam hal ini, digunakan kuesioner/ angket respon yang terdiri dari 8 pertanyaan berbentuk pilihan dengan tanda check list $(\sqrt{ })$.

Instrumen penelitian adalah lembar kuesioner atau angket dalam penelitian ini bertujuan untuk mengetahui respon siswa pada saat berlangsung pembelajaran dengan model Think Pair Share. Lembar tes yang digunakan untuk mengetahui kemampuan pemahaman konsep siswa tentang himpunan. Lembar pengamatan aktivitas siswa digunakan untuk melihat keterlibatan siswa dalam proses pembelajaran. Validitas bertujuan agar tes yang digunakan benar-benar untuk mengukur kemampuan siswa dalam menyelesaikan soal himpunan, maka instrumen yang telah disusun diukur dengan validitas tes. Rebialitas menunjukkan pada suatu pengertian bahwa suatu instrumen cukup dapat dipercaya untuk digunakan sebagai alat pengumpulan data karena instrumen tersebut sudah baik.

Berdasarkan hasil uji coba di MTs Nurushibyan Singkawang. Diperoleh nilai reliabilitas siswa sebesar 0,65. Dengan demikian, soal tes kemampuan pemahaman konsep siswa mempunyai reliabilitas dengan kategori sedang. Teknis Analisis Data setelah data penelitian terkumpul dari hasil pengumpulan data melalui angket, tes, dan lembar observasi. 


\section{HASIL DAN PEMBAHASAN}

Data kemampuan pemahaman konsep matematis siswa diperoleh dari hasil pre-test dan post-test. Skor pre-test dan post-test siswa ditampilkan dalam Tabel sebagai berikut:

Tabel 1 Rata-rata Pre-test dan Post-test

\begin{tabular}{ccc}
\hline Tes & Rata-rata $(\overline{\boldsymbol{x}})$ & Standar deviasi (SD) \\
pre-test & 31,99 & 10,11 \\
post-test & 72,58 & 8,39 \\
\hline
\end{tabular}

Berdasarkan Tabel tersebut diungkapkan bahwa nilai rata-rata hasil post-test lebih tinggi dibandingkan dengan nilai rata-rata hasil pre-test. Nilai rata-rata hasil pre-test adalah 31,99 dan nilai rata-rata hasil post-test adalah 72,58. Hal ini menunjukkan bahwa kemampuan pemahaman konsep matematis siswa meningkat setelah diberikan perlakuan dengan menggunakan model pembelajaran Think Pair Share. Untuk mengetahui apakah data tersebut berdistribusi normal atau tidak, maka digunakan rumus chikuadrat.

Hasil uji normalitas pre-test dan Post-test disajikan dalam Tabel sebagai berikut.

Tabel 2 Uji Nomalitas Pre-test dan Post-test

\begin{tabular}{cccccc}
\hline Kelompok & Sampel & Rata-rata & SD & $\chi_{\text {hitung }}^{2}$ & $\chi_{\text {tabel }}^{2}$ \\
\hline Pre-test & 31 & 34,23 & 7,97 & 2,1403 & 5,991 \\
Post-test & 31 & 69,68 & 8,37 & 4,863 & 5,991
\end{tabular}

Pengujian dilakukan pada taraf signifikan 0,05 untuk $\mathrm{n}=31$. Dari Tabel 4. 2 di atas diperoleh $\chi 2$ hitung Pre-test $<\chi 2$ tabel Pre-test atau 2,1403 $<5,991$,Sedangkan $\chi 2$ hitung Post-test $<\chi 2$ tabel Posttest atau 4,863 $<5,991$ sehingga dapat disimpulkan bahwa data pre-test dan post-test berdistribusi normal.

Berdasarkan uji-t perhitungan pre-test dan post-test diiperoleh nilai $t_{\text {hitung }}$ lebih besar daripada nilai $t_{\text {tabel, }}$ yaitu 32,47 > 2,0003. Hal ini berarti bahwa pada taraf signifikan 0,05 Ha diterima dan Ho ditolak. Dengan demikian berarti bahwa terdapat pengaruh model pembelajaran Think Pair Share terhadap kemampuan pemahaman konsep matematis siswa pada materi himpunan kelas VII MTs YASTI Shalahuddin Singkawang.

Persentase aktivitas belajar siswa dapat disajikan dalam Gambar sebagai berikut.

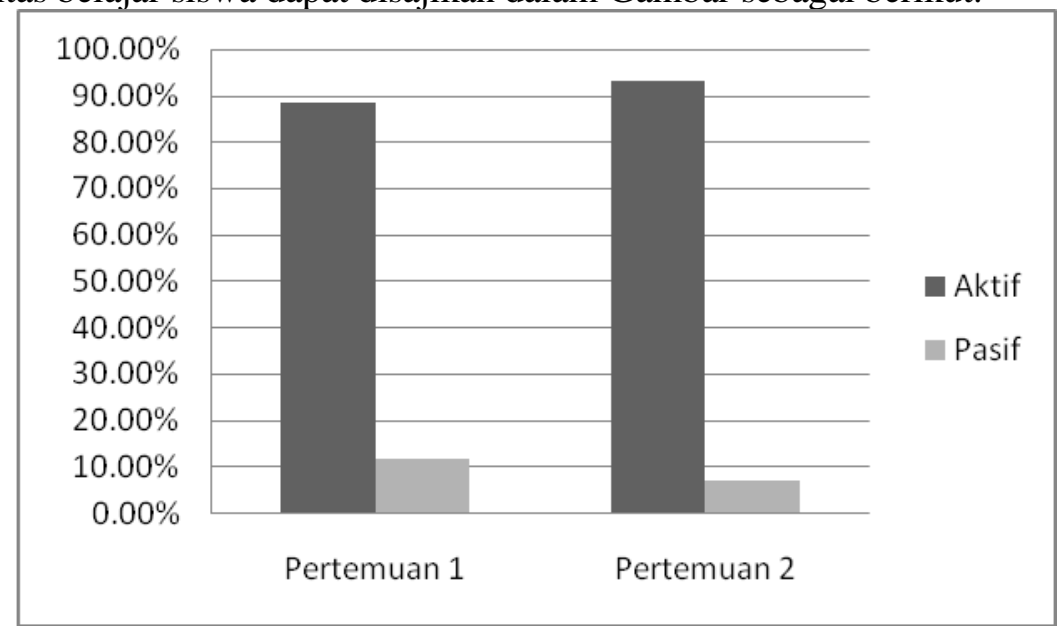

\section{Gambar 2 Diagram Batang Persentase Aktivitas Belajar Siswa}

Berdasarkan penjelasan hasil pengamatan aktivitas belajar siswa pada dua pertemuan persentase tingkah laku sikap aktif selalu lebih besar dibanding dengan tingkah laku sikap pasif. Dengan 
demikian, aktivitas siswa ketika diterapkannya model pembelajaran Think Pair Share pada siswa kelas VII MTs YASTI Shalahuddin Singkawang tergolong baik.

Untuk memperjelas tanggapan respon siswa pada pernyataan positif data dapat disajikan dalam Gambar:

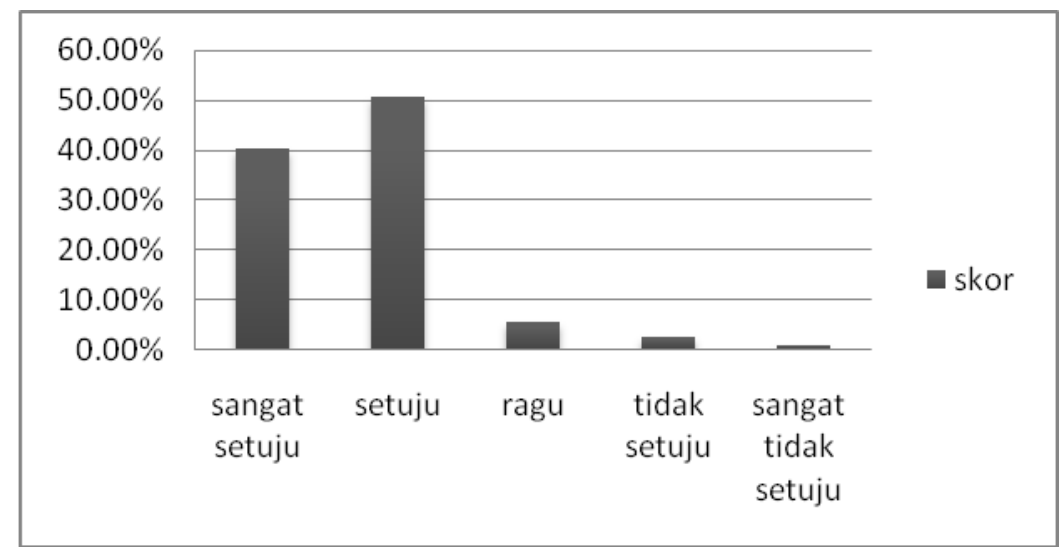

Gambar 3 Diagram Batang Persentase Respon Siswa Pada pernyataan Positif

Berdasarkan Gambar diagram batang persentase respon siswa pada pernyataan positif, tanggapan setuju dan sangat setuju lebih tinggi dibanding tanggapan ragu-ragu, tidak setuju, dan sangat tidak setuju.

Untuk memperjelas tanggapan respon siswa pada pernyataan negatif data dapat disajikan dalam Gambar:

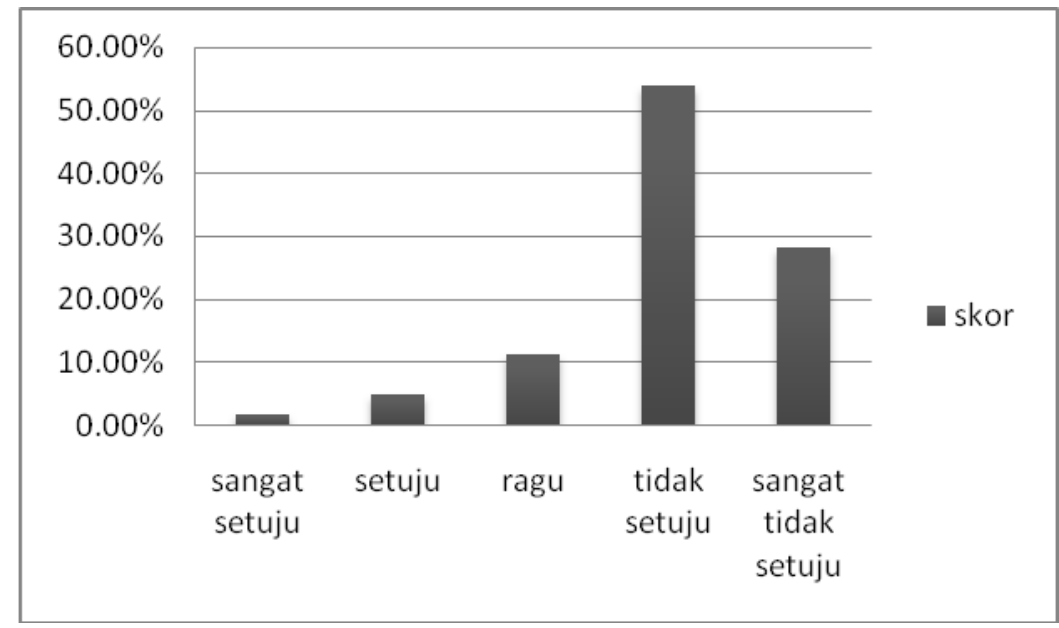

\section{Gambar 4 Diagram Batang Persentase Respon Siswa Pada Pernyataan Negatif}

Berdasarkan Gambar diagram batang persentase respon siswa pada pernyataan negatif, tanggapan ragu-ragu, tidak setuju, dan sangat tidak setuju lebih tinggi dibanding tanggapan setuju dan sangat setuju. Dengan demikian tanggapan pada pernyataan negatif tergolong respon positif.

Berdasarkan hasil persentase respon siswa pernyataan positif dan pernyataan negatif yang diperoleh, maka dapat dikatakan bahwa secara keseluruhan respon siswa positif terhadap model pembelajaran Think Pair Share pada materi himpunan.

\section{Pembahasan}

Berdasarkan pengolahan data kemampuan pemahaman konsep matematis siswa dengan pengujian normalitas data pre-test diperoleh nilai $\chi^{2}$ hitung $<\chi^{2}$ tabel, maka data berdistribusi normal dan 
pengujian normalitas data post-test diperoleh nilai bahwa $\chi^{2}$ hitung $<\chi^{2}$ tabel, maka data berdistribusi normal. Berdasarkan pengujian normalitas, didapatkan hasil bahwa data berdistribusi normal, maka selanjutnya pengujian hipotesis menggunakan uji-t dan diperoleh bahwa t_hitung $>\mathrm{t}$ ttabel, yaitu $32,47>2,0003$. Dengan demikian H_0 ditolak dan H_a diterima pada taraf signifikan $\alpha=0,05$ sehingga dapat disimpulkan bahwa terdapat pengaruh model pembelajaran Think Pair Share terhadap kemampuan pemahaman konsep matematis siswa pada materi himpunan kelas VII MTs YASTI Shalahuddin Singkawang. Hal ini relevan dengan hasil penelitian Darma (2009) ditemukan rata-rata kemampuan pemahaman konsep matematika lebih tinggi dengan model pembalajaran Think Pair Share daripada yang menggunakan model pembelajaran konvensional.

Aktivitas siswa ketika diterapkannya model pembelajaran Think Pair Share pada siswa kelas VII MTs YASTI Shalahuddin Singkawang tergolong baik, berdasarkan dari dua pertemuan pada pembelajaran pada materi himpunan selalu termasuk pada kategori sangat tinggi.Hal ini disebabkan selama proses model pembelajaran Think Pair Share yang diamati oleh peneliti banyak siswa berdiskusi antar teman tentang materi himpunan yaitu siswa bertanya kepada temannya ketika mengalami kesulitan dan ada siswa yang menjawab pertanyaan temannya yang mengalami kesulitan. Tidak hanya itu, siswa juga berpartisipasi aktif terhadap pembelajaran yaitu siswa bertanya kepada guru jika ada mengalami kesulitan, siswa menjawab pertanyaan yang diajukan oleh peneliti dan juga siswa dapat membuat kesimpulan terhadap jawaban.

Setelah perlakuan yang diberikan dengan model pembelajaran Think Pair Share selesai, kepada siswa diberikan angket respon untuk mengetahui tanggapan siswa selama proses pembelajaran berlangsung, siswa hanya memilih salah satu tanggapan yang telah disediakan. Pada penelitian ini respon siswa untuk pernyataan positif dan pernyataan negatif terhadap model pembelajaran Think Pair Share dapat diterima dengan baik. Hal ini dapat dilihat dari beberapa indikator, yaitu siswa merasa senang dan terdorong rasa ingin tahu terhadap materi selama mengikuti pembelajaran Think Pair Share pada materi himpunan. Kemudian ketika diberi tugas saat pembelajaran siswa merasa model pembelajaran Think pair Share menambah pengetahuan terhadap materi pembelajaran. Serta siswa merasa terbantu dalam mengingat konsep materi menggunakan model pembelajaran Think pair Share.

Secara umum dapat disimpulkan bahwa pembelajaran dengan model pembelajaran Think pair Share terdapat pengaruh terhadap materi himpunan di kelas VII MTs YASTI Shalahuddin Singkawang, sehingga aktivitas belajar siswa baik akibatnya respon siswa positif terhadap model pembelajaran Think pair Share. Hal ini sejalan dengan penelitian yang dilakukan oleh Darma (2009) respon siswa tergolong baik karena hampir secara keseluruhan respon siswa mendukung penerapan model pembelajaran Think Pair Share dalam materi perbandingan pada siswa kelas VII SMP Negeri 2 Singkawang.

\section{KESIMPULAN DAN SARAN}

\section{Kesimpulan}

Berdasarkan hasil pengelolahan data penelitian yang dilakukan, secara umum dapat disimpulkan bahwa terdapat pengaruh model pembelajaran Think Pair Share (TPS) terhadap kemampuan pemahaman konsep matematis siswa pada materi himpunan.

Secara khusus dapat disimpulkan beberapa hal sebagai berikut:

1. Terdapat pengaruh model pembelajaran Think Pair Share terhadap kemampuan pemahaman konsep matematis siswa pada materi himpunan kelas VII MTs YASTI Shalahuddin Singkawang.

2. Pengaruh model pembelajaran Think Pair Share terhadap aktivitas belajar siswa pada materi himpunan di kelas VII MTs YASTI Shalahuddin Singkawang tergolong baik

3. Pengaruh model pembelajaran Think Pair Share terhadap respon belajar siswa pada materi himpunan di kelas VII MTs YASTI Shalahuddin Singkawang tergolong baik dilihat dari 
persentase pernyataan positif

\section{Saran}

Berdasarkan hasil penelitian, saran dalam penelitian ini yaitu:

1. Sebaiknya kemampuan pemahaman konsep matematis siswa dengan model pembelajaran Think Pair Share (TPS) diajarkan di sekolah, karena model pembelajaran TPS berpengaruh terhadap kemampuan pemahaman konsep matematis siswa.

2. Sebaiknya model pembelajaran Think Pair Share (TPS) digunakan sebagai salah satu alternatif pembelajaran yang dilaksanakan di sekolah, sebab TPS dapat meningkatkan aktivitas siswa.

3. Sebaiknya guru memberi motivasi kepada siswa agar tidak takut membuat kesalahan dalam kegiatan pembelajaran menggunakanTPS, sebab siswa cenderung takut untuk mencoba.

4. Kepada peneliti yang ingin melakukan penelitian seperti ini apabila penulis melakukan kesalahan atau kesulitan untuk tidak diulangi lagi oleh penelitilain agar diperoleh hasil yang lebih baik.

\section{DAFTAR PUSTAKA}

Apriana, Ristia. (2009). Pembelajaran Matematika Menggunakan Metode Permainan Bola Pimpong Pada Materi Operasi Hitung Bilangan Bulat Dikelas V SD Negeri 19 Pontianak Timur. SKRIPSI. STKIP-PGRI Pontianak.

Buyung.(2015). Pengaruh Strategi Pembelajaran Inkuiri (SPI) Terhadap Peningkatan Kemampuan Pemahaman Konsep Siswa Pada Persamaan Garis Lurus Kelas VII SMP Negeri 18 Singkawang Selatan. SKRIPSI. STKIP Singkawang.

Buyung, B., \& Dwijanto, D. (2017). Analisis Kemampuan Literasi Matematis melalui Pembelajaran Inkuiri dengan Strategi Scaffolding. Unnes Journal of Mathematics Education Research, 6(1), 112-119.

Darma, Yudi. (2009). Penerapan Pembelajaran dengan Metode Heuristic dalam Materi Barisan dan Deret pada Siswa Kelas XII Madrasah Aliyah Negeri 2 Pontianak. Skripsi. Pontianak: STKIP-PGRI Pontianak.

Depdiknas. (2006). Peraturan Pengembangan Menteri Pendidika Nasional Republik Indonesia Tentang Standar Isi untuk Satuan Pendidikan Dasar dan Menengah. Jakarta: Depdiknas.

Hamzah, Ali dan Muhlisrarini. (2013). Perencanaan Dan Strategi Pembelajaran Matematika. Jakarta: charisma putra utama offset.

Hanafiah, Nanang. (2009). Konsep Strategi Pembelajaran. Bandung: Refika Aditama.

Ibrahim, Muslimin, dkk.(2000). Pembelajaran Kooperatif. Surabaya: Univerity Press.

Murizal, Angga, dkk. (2012). Pemahaman Konsep Matematis Siswa dan Model Pembelajaran .Jurnal Pendidikan Matematika, Jurusan Matematika FMIPA UNP. Hal. 19-23.

Novita, Rita. (2014). Hasil Belajar Siswa pada Persamaan Kuadrat dalam Pembelajaran Model Pembelajaran Think Pair Share di SMA Negeri 8 Banda Aceh. Jurnal. STKIP Bina Bangsa Meulaboh.

Sugiyono. (2011). Metode Penelitian Kuantitatif Kualitatif Dan R\&D. Bandung: ALFABETA.

Sutiarni, Rizma. (2013). Efektivitas Model Pembelajaran Kooperatif Tipe Think Pair Share Dalam Materi Perbandingan Pada Siswa Kelas VII SMP Negeri 2 Singkawang. Skripsi. STKIP PGRI Pontianak. 